\title{
A DESCRIPTION OF THE CHARACTERISTICS OF HEPATIC CIRRHOSIS PATIENT IN ABDUL WAHAB SJAHRANIE REGIONAL PUBLIC HOSPITAL SAMARINDA
}

\author{
Tri Wulandari ${ }^{1, *}$, Nirapambudi Devianto ${ }^{2}$, and Fransiska A. Sihotang ${ }^{3}$ \\ ${ }^{1}$ Medicine Study Program, School of Medicine, Mulawarman University, Samarinda \\ ${ }^{2}$ Laboratory of Internal Medicine, School of Medicine, Mulawarman University, Samarinda \\ ${ }^{3}$ Laboratory of Pyschology, School of Medicine, Mulawarman University, Samarinda \\ *E-mail : tri.wulandari.3797@gmail.com
}

\begin{abstract}
Hepatic cirrhosis is a late stage liver disease characterized by the replacement of normal hepatocyte cells with fibrosis tissue. The severity of hepatic cirrhosis can be determined using Child-Pugh criteria which are divided into Grades A, B and C. This study aimed to find out the characteristics of hepatic cirrhosis patients in Abdul Wahab Sjahranie Regional Public Hospital in Samarinda. The design of this study was descriptive observational. Participants in this study consisted of 58 hepatic cirrhosis patients who were hospitalized in Abdul Wahab Sjahranie Regional Public Hospital in Samarinda from June

2017 to June 2018. Variables in this study were age, gender, period of stay, conditions at discharge, and the severity of cirrhosis. The researchers used data from medical records of cirrhosis patients. From 58 participants in this study, they were mostly people in the age of $46-55$ years $(43.1 \%)$ and the majority were male (70.7\%). The maximum period of stay in hospital was less than 1 week $(58.6 \%)$ and the condition when they went back home were mostly with outpatient treatment $(79.3 \%)$. The severe degree of cirrhosis that was found was Child-Pugh C (63.8\%).
\end{abstract}

Keywords: Hepatic Cirrhosis, Child-Pugh, Severity

\section{INTRODUCTION}

Hepatic cirrhosis is a late-stage disease characterized by the replacement of normal hepatocyte cells with fibrosis tissue ${ }^{1}$. The occurrence of cirrhosis in the United States continues to increase in the last ten years. In 2008, there were an estimated $18 \%$ of new cases of hepatic cirrhosis in the United States and were expected to continue to increase each year. This increase is due to the high rate of alcohol consumption which is a risk factor for alcoholic hepatitis that develops into cirrhosis ${ }^{2}$. In Asia, the highest occurrence of cirrhosis is found in Thailand ${ }^{3}$. A total of 9,131 deaths occur annually in Thailand due to cirrhosis or about $8.9 \%$ per 100,000 population $^{4}$. The latest data from the Indonesian Ministry of Health in 2008, cirrhosis occupies the 8th position as the cause of death in Indonesia or around $5.1 \%$ of all deaths in Indonesia ${ }^{5}$. At the Dr. Kariadi Hospital in Semarang, around $19.8 \%$ of the 362 liver cirrhosis patients whom were treated died within 3 years ${ }^{6}$. Hepatic cirrhosis is clinically divided into compensatory and decompensated. Decompensated cirrhosis is often accompanied by complications of liver disease that requires a liver transplant. The most difficult one is portal hypertension which can cause complications in the form of ascites and bleeding esophageal varices ${ }^{7}$. The severity of cirrhosis is related to its prognosis which can be assessed using Child-Pugh criteria as a valid predictor in predicting patient survival. The Child-Pugh criteria consists of five parameters, such as serum bilirubin, serum albumin, ascites, prolongation of prothrombin which describes the function of liver metabolism and hepatic encephalopathy which describes the severity of portal hypertension ${ }^{8}$. 


\section{MATERIAL AND METHOD}

The design of this research was descriptive observational study with cross sectional approach that aimed to determine the characteristics of hepatic cirrhosis patients in the Internal Medicine Unit at Abdul Wahab Sjahranie Hospital in Samarinda. Data was in the form of secondary data taken from the medical records of hepatic cirrhosis patients who were hospitalized in the Internal Medicine Unit of Abdul Wahab Hospital Sjahranie Samarinda.

The inclusion criteria in this study were patients diagnosed with liver cirrhosis by a specialist in Internal Medicine and were hospitalized in the Internal Medicine Ward Unit at Abdul Wahab Sjahranie Hospital Samarinda. Exclusion criteria were patients with incomplete medical record and did not include the variables that would be studied in this study.

Data analysis used SPSS Statistics 23. This study had received ethical approval from the Health Research Ethics Committee of Abdul Wahab Sjahranie Samarinda Hospital.

\section{RESULTS AND DISCUSSION}

The number of participants in this study were 58 people. The results of the study included age, gender, period of hospitalization, the state of disability, and the levelof severity. The results of this study can be seen in table 1 .

Table 1. Demographic Characteristics of Hepatic Cirrhosis Patients in Internal Medicine Unit of Abdul Wahab Sjahranie Hospital Samarinda from June 2017 - June 2018.

\begin{tabular}{lcc}
\hline \multicolumn{1}{c}{ Characteristics } & $\begin{array}{c}\text { Total } \\
(\mathbf{N}=\mathbf{5 8})\end{array}$ & $\begin{array}{c}\text { Percentage } \\
(\mathbf{\%})\end{array}$ \\
\hline Age & 0 & \\
$<26$ years & 2 & 0 \\
$<26-35$ years & 13 & 22,4 \\
36-45 years & 25 & 43,1 \\
46-55 years & 14 & 24,1 \\
56-65 years & 4 & 6,9 \\
> 65 years & & \\
Gender & 41 & 70,7 \\
Male & 17 & 29,3 \\
Female & & \\
Period of Hospitalization & 34 & 58,6 \\
$<1$ week & 16 & 27,6 \\
1 - 2 week & 8 & 13,8 \\
> 2 week & & \\
Condition at Discharge & 46 & 79,3 \\
Outpatient & 12 & 20,7 \\
Death & 0 & 0 \\
Discharged by their own request & & \\
Level of Severity & 0 & 0 \\
$\quad$ Child-Pugh A & 21 & 36,2 \\
$\quad$ Child-Pugh B & 37 & 63,8 \\
$\quad$ Child-Pugh C & & \\
\hline
\end{tabular}


The age of cirrhosis patients in this study was divided into six groups, such as age $<26$ years, 26-35 years, 36-45 years, 46-55 years, 56-65 years and $>65$ years. The grouping is based on the Republic of Indonesia's Ministry of Health guidelines in $2009^{9}$. In this study, the majority of subjects were elderly in the age group of 46-55 years. Research with similar result was carried out by Lovena, Miro, \& Efrida in Padang. Hepatic cirrhosis is a chronic liver disease that is more common happen to the elderly ${ }^{10}$. The slow progression of the disease is also one of the factors that many patients would detect it later when they get much older due to the symptoms and signs of the disease which only appear years later after the patient is exposed to risk factors for liver disease for a long time such as hepatitis $\mathrm{B}^{11}$.

It is found that male were found to suffer more from cirrhosis. Research with similar result was conducted by Patasik, Waleleng, \& Wantana in Manado ${ }^{12}$. Cirrhosis is more common in male, it is expected because of the role of male as heads of families who have to work hard therefore it can affect their health and are more at risk of disease even though the cause have not been found yet ${ }^{13}$. Another factor that might play a role is the social environment, especially the habit of consuming alcohol in male ${ }^{10}$.

The period of hospitalization was in the span of $<1$ week, as many as 34 patients $(58.6 \%)$. Research with similar result was conducted by Muhammad in Abdul Wahab Sjahranie Hospital in Samarinda, and as many as 16 patients $(47 \%)$ were treated within 1 week $^{14}$. The period of hospitalization depends on complications that arise since it affects the length of treatment period. Decompensated hepatic cirrhosis patients are tend to go through a longer treatment because of more complex therapies procedures. Patients' condition also affects how long they would stay in hospital, for example, if their condition is generally bad, they tend to have a higher risk of death during the treatment period ${ }^{15}$.

The most common condition when the patient was discharged was outpatient treatment for 46 patients (79.3\%), followed by death for 12 patients (20.7\%) and none discharged by their own request. Patients who died in this study were suffered from cirrhosis with complications such as hepatic encephalopathy, kidney disorders, hypoalbuminemia and hypovolemic shock and there was one patient who died from cardiac arrest. Research with similar result was conducted by Stiphany, Hiswani, \& Jemadidi Medan ${ }^{11}$. In this study, patients who were allowed to go home were patients with improved general condition and had received therapy for cirrhosis and its complications, therefore, by maintaining their nutritional needs, the patient could continue the treatment at home. For example, in the case of cirrhosis with bleeding esophageal varices that have been through ligase and with good general condition could continue their treatment at home.

About $50-60 \%$ of patients with esophageal varices would experience bleeding, and the mortality rate from the first episode of bleeding was around $17-57 \%$. This made many cirrhosis patients opted to outpatient to monitor their health condition and risk of recurrent bleeding, especially in cirrhosis with esophageal varices ${ }^{16}$. Hepatic cirrhosis mortality rate in Dr. Kariadi Hospital in Semarang in 2010-2012 was 19.8\%. This was caused by the large number of hepatic cirrhosis patients who came with Child-Pugh $\mathrm{C}$ which meant the patient came with a poor liver function so that the risk of death would be higher. Whereas for patients with hepatic cirrhosis Child-Pugh A and Child-Pugh B, they experienced more improvement in conditions hence they were allowed to go home and chose outpatient treatment. Other causes of death were complications such as bleeding esophageal variceal, hepatic encephalopathy, hepatocellular 
carcinoma, hepatorenal syndrome, ascites, spontaneous bacterial peritonitis, and Portal hypertensive gastropathy ${ }^{6}$.

The researchers found that the most severe degree of cirrhosis in Samarinda was Child-Pugh C, followed by Child-Pugh B, and there were no patients with Child-Pugh A. Similar study was conducted by Muhammad in Samarinda ${ }^{14}$. This could happen since hepatic cirrhosis is a disease in which most patients remain asymptomatic until the emergence of signs of decompensation that bring patients to health facilities, such as ascites, edema and icterus which appear more in patients with cirrhosis with moderate and severe disease ${ }^{17}$. Other risk factors include complications, the patient's general condition and comorbid diseases such as pleural effusion, pneumonia, sepsis and heart disease ${ }^{6}$.

\section{CONCLUSION}

In this study, the most hepatic cirrhosis patients were in the age range of 45-55 years and dominated by male patients. The period of hospitalization of hepatic cirrhosis patients was mostly in the span of $<1$ week and there were more hepatic cirrhosis patients who went home with outpatient status to evaluate the patient's condition. Whereas the most commonly found severity of hepatic cirrhosis based on the Child-Pugh classification was Child-Pugh C.

\section{REFERENCE}

1. EASL. Fast facts about liver disease. 1. Union E, Hcc N, Hepat. H. Fast facts about liver Dis. 2013;15-8. 15-18 (2016). doi:10.1007/BF02424977

2. Flamm, S. L. Complications of Cirrhosis in Primary Care: Recognition and Management of Hepatic Encephalopathy. Am. J. Med. Sci.356, 296-303 (2018).

3. Wong, M. C. S. \& Huang, J. The growing burden of liver cirrhosis: implications for preventive measures. Hepatol. Int.12, 201-203 (2018).

4. Rattanamongkolgul, S., Wongjitrat, C., \&Puapankitcharoen, P.Prevalence of Cirrhosis Registered in NakhonNayok, Thailand.Medical Association of Thailand. 93(2), S87-S91 (2010).

5. KementerianKesehatanRepublikIndonesia.ProfilKesehatan

Indonesia 2008. Jakarta: DepartemenKesehatanRepublik Indonesia (2009).

6. Marselina, N. M. T. Gambaran Klinis Pasien Sirosis Hati: Studi Kasus di RSUP Dr Kariadi Semarang Periode 2010-2012. (2014).

7. Bacon, B. R, 2014, SirosisdanPenyulitnya, in: D. L. Longo, \& A. S. Fauchi, Harrison GastroenterologidanHepatologi (Brahm U. Pendit trans.), EGC, Jakarta,pp. 374-386.

8. Doubatty, A. C. Perbandingan Validitas Skor Mayo End Stage Liver Disease Dan Skor Child-Pugh Dalam Memprediksi Ketahanan Hidup 12 Minggu Pada Pasien Sirosis Hepatis. 10-31 (2009).

9. Santika, I. G. P. N. A. Hubungan Indeks Masa Tubuh (IMT) dan Umur terhadap Daya Tahan umum (Kardiovaskuler) Mahasiswa Putra Semester II Kelas A Fakultas Pendidikan Olahraga dan Kesehatan IKIP PGRI Bali Tahun 2014. J. Pendidik. Kesehat. rekreasi1, 42-47 (2015).

10. Lovena, A., Miro, S. \& Efrida. Karakteristik Pasien Sirosis Hepatis di RSUP Dr. M. Djamil Padang. J. Kesehat. Andalas6, 5-12 (2017).

11. Stiphany, Hiswani \& Jemadi. Karakteristik Penderita Sirosis Hati Rawat Inap di RSUD DR Pirngadi Medan Tahun 2010-2011. (7540BC). 
12. Patasik, Y. Z., Waleleng, B. J. \& Wantania, F. Profil Pasien Sirosis Hati Yang Dirawat Inap Di Rsup Prof. Dr. R. D. Kandou Manado Periode Agustus 2012 - Agustus 2014. eCliniC3, 3-8 (2015).

13. Simamora, C. T. A. Hubungan Komplikasi, Skor Child-Turcotte, dan Usia Lanjut sebagai Faktor Risiko Kematian pada Pasien Sirosis Hati di RSUD Dr. Soedarso Pontianak Tahun 2008-2012. (2013).

14. Muhammad, I. Hubungan antara Kadar Hemoglobin dengan Tingkat Keparahan Sirosis Hati Berdasarkan Klasifikasi Child-Pugh pada Pasien yang dirawat inap di RSUD Abdul Wahab Sjahranie Samarinda. (2013).

15. Nurdjanah, S, 2015, SirosisHati. In S. Setiati, I.Alwi, A. W. Sudoyo, M. Simadibarata K, B. Setiyohadi, \& A. F. Syam (Eds. 6), Buku Ajar IlmuPenyakitDalam, Interna Publishing, Jakarta, pp. 1980-1985.

16. Vidyani, A., Vianto, D., Budi, Kholili, U., Maimunah, U., Sugihartono, T., et al. FaktorRisikoTerkaitPerdarahanVarisesEsofagusBerulangPadaPenderitaSirosisHati.JurnalPenyakit Dalam12(3), 169-174 (2011).

17. Tambunan, A. Karakteristik Pasien Sirosis hati di RSUD Dr. Soedarso Pontianak Periode Januari 2008-Desember 2010. 1-19 (2011). 